\title{
Cucurbitane Triterpenoids from Momordica charantia and Their Cytoprotective Activity in tert-Butyl Hydroperoxide-Induced Hepatotoxicity of HepG2 Cells
}

\author{
Chiy-Rong Chen, ${ }^{a}$ Yun-Wen Liao, ${ }^{b}$ Lai WAnG,${ }^{b}$ Yueh-Hsiung Kuo, ${ }^{c, \#}$ Hung-Jen Liv, ${ }^{d}$ \\ Wen-Ling $\mathrm{SHIH}^{b}{ }^{b}$ Hsueh-Ling $\mathrm{CHENG}^{b}$ and Chi-I CHANG ${ }^{*, b, \#}$ \\ ${ }^{a}$ Department of Biological Science and Technology, Meiho University; Pingtung 91201, Taiwan: ${ }^{b}$ Graduate Institute of \\ Biotechnology, National Pingtung University of Science and Technology; Pingtung 91201, Taiwan: ${ }^{c}$ Tsuzuki Institute for \\ Traditional Medicine, College of Pharmacy, China Medical University; Taichung 40402, Taiwan: and Institute of \\ Molecular Biology, National Chung-Hsing University; Taichung 40227, Taiwan. \\ Received June 6, 2010; accepted September 2, 2010; published online September 6, 2010
}

Two novel pentanorcucurbitane triterpenes, 22-hydroxy-23,24,25,26,27-pentanorcucurbit-5-en-3-one (1) and 3,7-dioxo-23,24,25,26,27-pentanorcucurbit-5-en-22-oic acid (2) together with a new trinorcucurbitane triterpene, 25,26,27-trinorcucurbit-5-ene-3,7,23-trione (3) were isolated from the methyl alcohol extract of the stems of Momordica charantia. The structures of the new compounds were elucidated by spectroscopic methods. Compounds 2 and 3 showed potent cytoprotective activity in tert-butyl hydroperoxide ( $t$-BHP)-induced hepatotoxicity of HepG2 cells.

Key words Chinese herb; Momordica charantia; Cucurbitaceae; pentanorcucurbitane; trinorcucurbitane; cytoprotective

Momordica charantia L., a slender-stemmed tendril climber, belongs to the family Cucurbitaceae and is commonly known as bitter gourd or bitter melon. It is wildly cultivated as a vegetable crop in tropical and subtropical areas, including Asia, East Africa, and South America. Tissues of this plant have extensively been used as folk medicine for the treatment of diabetes and diseases of liver in Taiwan. The previous pharmacological studies have demonstrated that the extracts or constituents of tissues of $M$. charantia possess anti-diabetic and anti-inflammatory activities. ${ }^{1-3)}$ The $\mathrm{Cu}$ curbitaceae plants have been recognized as rich sources of cucurbitane-type triterpenoids possessing anti-diabetic activity. ${ }^{3)}$ More than seventy cucurbitane-type triterpenoids have been identified from the fruits, ${ }^{3-10)}$ seeds, ${ }^{11,12)}$ roots, ${ }^{13)}$ leaves and vines ${ }^{14,15)}$ of $M$. charantia. As part of our program aimed at the discovery of the cucurbitane-type triterpenes from $M$. charantia originated in Taiwan, we have reported the isolation and structure elucidation of 21 cucurbitane-type triterpenoids from the $\mathrm{MeOH}$ extract of the stems of this plant. ${ }^{16-18)}$ In our continuing investigation on the same extract, we further isolated two novel pentanorcucurbitane triterpenes, 22-hydroxy-23,24,25,26,27-pentanorcucurbit-5en-3-one (1) and 3,7-dioxo-23,24,25,26,27-pentanorcucurbit5-en-22-oic acid (2), as well as a novel trinorcucurbitane triterpene, 25,26,27-trinorcucurbit-5-ene-3,7,23-trione (3) (Fig. 1). In this paper, we describe the isolation and structure elucidation of compounds $\mathbf{1}-\mathbf{3}$ and the cytoprotective activities of compounds $\mathbf{2}$ and $\mathbf{3}$ in tert-butyl hydroperoxide ( $t$ BHP)-induced hepatotoxicity of HepG2 cells.
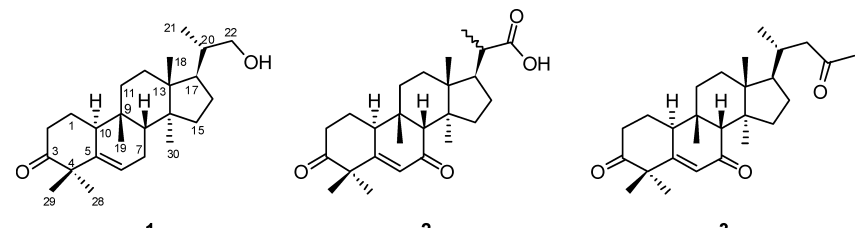

Fig. 1. Structures of Compounds $\mathbf{1}-\mathbf{3}$ from $M$. charantia

\section{Results and Discussion}

Compound 1 was obtained as a white amorphous powder. The IR spectrum suggested the presence of hydroxy $\left(3422 \mathrm{~cm}^{-1}\right)$, double bond $\left(3075,1654 \mathrm{~cm}^{-1}\right)$, and isolated ketone $\left(1708 \mathrm{~cm}^{-1}\right)$ absorptions. The ${ }^{1} \mathrm{H}-$ and ${ }^{13} \mathrm{C}-\mathrm{NMR}$ spectra of 1 (Table 1) contained signals for five methyl singlets $\left[\delta_{\mathrm{H}} 0.84,0.86,0.87,1.19,1.22(3 \mathrm{H}\right.$ each, s)], one methyl doublet $\left[\delta_{\mathrm{H}} 1.00(3 \mathrm{H}, \mathrm{d}, J=5.6 \mathrm{~Hz})\right]$, a trisubstituted double bond $\left[\delta_{\mathrm{H}} 5.64(1 \mathrm{H}, \mathrm{m}) ; \delta_{\mathrm{C}} 120.3(\mathrm{~d}), 142.5(\mathrm{~s})\right]$, and an ABX splitting pattern of secondary alcohol $[3.31(1 \mathrm{H}, \mathrm{d}$, $\left.J=6.4,10.4 \mathrm{~Hz}), 3.62(1 \mathrm{H}, \mathrm{d}, J=2.4,10.4 \mathrm{~Hz}) ; \delta_{\mathrm{C}} 68.2(\mathrm{t})\right]$. The ${ }^{13} \mathrm{C}-\mathrm{NMR}$ spectrum of $\mathbf{1}$ revealed 25 carbon signals, which were assigned by the distortionless enhancement by polarization transfer (DEPT) experiments as six aliphatic methyl, seven aliphatic methylene, four aliphatic methine, four aliphatic quaternary, one oxygenated methylene, one olefinic methine, one quaternary olefinic, and one isolated ketone carbonyl carbons. Its high resolution electron impact mass spectrum (HR-EI-MS) exhibited a molecular ion at $\mathrm{m} / \mathrm{z}$ 372.3048 , consistent with the molecular formula, $\mathrm{C}_{25} \mathrm{H}_{40} \mathrm{O}_{2}$, which indicated six degrees of unsaturation. Two degrees of unsaturation were attributable to a trisubstituted olefin and a ketone group, and the remaining four units of unsaturation were accounted for the tetracyclic skeleton. On the basis of the fact that the major tetracyclic triterpenoids presenting in the genus Momordica plants are cucurbitane-type triterpenes, compound 1 was tentatively proposed to be a 23,24,25,26,27pentanorcucurbitacin derivative. By comparison of the ${ }^{1} \mathrm{H}$ and ${ }^{13} \mathrm{C}-\mathrm{NMR}$ data with those of the known compound, (23E)-25-hydroxycucurbita-5,23-diene-3,7-dione, ${ }^{16)}$ indicated that both compounds exhibited identical structure in rings $\mathrm{A}-\mathrm{D}$ of the tetracyclic skeleton and the ${ }^{13} \mathrm{C}-\mathrm{NMR}$ signals of $\mathrm{C}-23-\mathrm{C}-27$ of the side chain were absent in $\mathbf{1}$. Thus, compound 1 was considered as a 23,24,25,26,27-pentanorcucurbitacin triterpene. The planar structure of 1 was constructed by the ${ }^{1} \mathrm{H}-{ }^{1} \mathrm{H}$ correlated spectroscopy (COSY), heteronuclear multiple-quantum coherence (HMQC), and heteronuclear multiple bond coherence (HMBC) spectra. The HMBC cor- 
Table 1. ${ }^{1} \mathrm{H}$ - and ${ }^{13} \mathrm{C}-\mathrm{NMR}$ Data for $\mathbf{1}-\mathbf{3}\left(400,100 \mathrm{MHz}\right.$ in $\left.\mathrm{CDCl}_{3}\right)$

\begin{tabular}{|c|c|c|c|c|c|c|}
\hline \multirow{2}{*}{ Position } & \multicolumn{2}{|r|}{1} & \multicolumn{2}{|r|}{2} & \multicolumn{2}{|c|}{3} \\
\hline & $\delta_{\mathrm{C}}$ & $\delta_{\mathrm{H}}$ & $\delta_{\mathrm{C}}$ & $\delta_{\mathrm{H}}$ & $\delta_{\mathrm{C}}$ & $\delta_{\mathrm{H}}$ \\
\hline 1 & 25.7 & $1.49 \mathrm{~m}, 2.01 \mathrm{~m}$ & 23.6 & $1.65 \mathrm{~m}, 2.12 \mathrm{~m}$ & 23.6 & $1.64 \mathrm{~m}, 2.12 \mathrm{~m}$ \\
\hline 2 & 38.6 & $2.39 \mathrm{~m}, 2.58 \mathrm{~m}$ & 38.1 & $2.52 \mathrm{~m}, 2.62 \mathrm{~m}$ & 38.2 & $2.52 \mathrm{~m}, 2.62 \mathrm{~m}$ \\
\hline 3 & 215.2 & & 211.4 & & 211.8 & \\
\hline 4 & 50.9 & & 51.5 & & 51.5 & \\
\hline 5 & 142.5 & & 167.8 & & 168.0 & \\
\hline 6 & 120.3 & $5.64 \mathrm{~m}$ & 125.4 & $6.15 \mathrm{~d}(2.4)$ & 125.4 & $6.14 \mathrm{~d}(2.0)$ \\
\hline 7 & 24.5 & $1.86 \mathrm{~m}, 2.38 \mathrm{~m}$ & 202.3 & & 202.3 & \\
\hline 8 & 43.2 & $1.78 \mathrm{~m}$ & 59.0 & $2.43 \mathrm{~s}$ & 59.2 & $2.42 \mathrm{~s}$ \\
\hline 9 & 34.9 & & 36.8 & & 36.8 & \\
\hline 10 & 38.5 & $2.55 \mathrm{~m}$ & 41.1 & 2.92 ddd $(2.0,4.0,11.6)$ & 41.3 & $2.89 \mathrm{~m}$ \\
\hline 11 & 32.1 & $1.50 \mathrm{~m}, 1.70 \mathrm{~m}$ & 31.2 & $1.55 \mathrm{~m}, 1.84 \mathrm{~m}$ & 31.3 & $1.58 \mathrm{~m}, 1.80 \mathrm{~m}$ \\
\hline 12 & 30.2 & $1.45 \mathrm{~m}, 1.55 \mathrm{~m}$ & 29.8 & $1.58 \mathrm{~m}, 1.89 \mathrm{~m}$ & 29.8 & $1.62 \mathrm{~m}, 1.78 \mathrm{~m}$ \\
\hline 13 & 46.3 & & 45.9 & & 46.0 & \\
\hline 14 & 49.0 & & 48.4 & & 48.7 & \\
\hline 15 & 34.9 & $1.16 \mathrm{~m}, 1.26 \mathrm{~m}$ & 34.6 & $1.14 \mathrm{~m}, 1.58 \mathrm{~m}$ & 34.6 & $1.12 \mathrm{~m}, 1.58 \mathrm{~m}$ \\
\hline 16 & 27.3 & $1.32 \mathrm{~m}, 1.88 \mathrm{~m}$ & 26.7 & $1.41 \mathrm{~m}, 1.91 \mathrm{~m}$ & 28.0 & $1.52 \mathrm{~m}, 1.84 \mathrm{~m}$ \\
\hline 17 & 46.8 & $1.60 \mathrm{~m}$ & 46.7 & $1.97 \mathrm{~m}$ & 49.8 & $1.50 \mathrm{~m}$ \\
\hline 18 & 15.5 & $0.87 \mathrm{~s}$ & 15.7 & $0.90 \mathrm{~s}$ & 15.5 & $0.92 \mathrm{~s}$ \\
\hline 19 & 27.2 & $0.86 \mathrm{~s}$ & 27.2 & $0.94 \mathrm{~s}$ & 27.3 & $0.93 \mathrm{~s}$ \\
\hline 20 & 39.0 & $1.68 \mathrm{~m}$ & 42.2 & $2.50 \mathrm{~m}$ & 32.9 & $2.06 \mathrm{~m}$ \\
\hline 21 & 16.8 & $1.00 \mathrm{~d}(5.6)$ & 17.3 & $1.21 \mathrm{~d}(6.8)$ & 19.9 & $0.89 \mathrm{~d}(6.4)$ \\
\hline 22 & 68.2 & $\begin{array}{l}3.31 \mathrm{dd}(6.4,10.4) \\
3.62 \mathrm{dd}(2.4,10.4)\end{array}$ & 180.9 & & 51.1 & $2.16 \mathrm{~m}, 2.48 \mathrm{~m}$ \\
\hline 23 & & & & & 209.4 & \\
\hline 24 & & & & & 30.8 & $2.10 \mathrm{~s}$ \\
\hline 28 & 28.6 & $1.19 \mathrm{~s}$ & 28.4 & $1.31 \mathrm{~s}$ & 28.5 & $1.33 \mathrm{~s}$ \\
\hline 29 & 22.6 & $1.22 \mathrm{~s}$ & 23.0 & $1.34 \mathrm{~s}$ & 23.2 & $1.31 \mathrm{~s}$ \\
\hline 30 & 17.7 & $0.84 \mathrm{~s}$ & 17.9 & $0.91 \mathrm{~s}$ & 18.1 & $0.87 \mathrm{~s}$ \\
\hline
\end{tabular}

relations between $\mathrm{H}-1\left(\delta_{\mathrm{H}} 1.49,2.01\right) / \mathrm{C}-3\left(\delta_{\mathrm{C}} 215.2\right), \mathrm{C}-5$ $\left(\delta_{\mathrm{C}} 142.5\right), \mathrm{C}-10\left(\delta_{\mathrm{C}} 38.5\right) ; \mathrm{H}-6\left(\delta_{\mathrm{H}} 5.64\right) / \mathrm{C}-4\left(\delta_{\mathrm{C}} 50.9\right), \mathrm{C}-$ $5, \mathrm{C}-7\left(\delta_{\mathrm{C}} 24.5\right), \mathrm{C}-8\left(\delta_{\mathrm{C}} 43.2\right), \mathrm{C}-10$ (Fig. 2$)$ confirmed that the isolated ketone and the trisubstituted double bond were located at C-3 and C-5,6 positions, respectively. The hydroxy group was attached on $\mathrm{C}-22$ was assured by the HMBC correlations between $\mathrm{H}-22\left(\delta_{\mathrm{H}} 3.31,3.62\right) / \mathrm{C}-17\left(\delta_{\mathrm{C}} 46.8\right), \mathrm{C}-20$ $\left(\delta_{\mathrm{C}} 39.0\right), \mathrm{C}-21\left(\delta_{\mathrm{C}} 16.8\right)$ (Fig. 2$)$. The relative configurations of sterogenic $\mathrm{C}$-atoms in the tetracyclic rings were determined by significant nuclear Overhauser effect (NOE) correlations between $\mathrm{H}-8\left(\delta_{\mathrm{H}} 1.78\right) / \mathrm{Me}-18\left(\delta_{\mathrm{H}} 0.87\right), \mathrm{Me}-19\left(\delta_{\mathrm{H}}\right.$ $0.86) ; \mathrm{H}-10 / \mathrm{Me}-28\left(\delta_{\mathrm{H}} 1.19\right), \mathrm{Me}-30\left(\delta_{\mathrm{H}} 0.84\right) ; \mathrm{H}-17\left(\delta_{\mathrm{H}}\right.$ $1.60) / \mathrm{Me}-30\left(\delta_{\mathrm{H}} 0.84\right)$ in the nuclear Overhauser enhancement exchange spectroscopy (NOESY) spectrum (Fig. 3). The NOESY correlations between $\mathrm{H}-20\left(\delta_{\mathrm{H}} 1.68\right) / \mathrm{Me}-18$; $\operatorname{Me}-21\left(\delta_{\mathrm{H}} 1.00\right) / \mathrm{H}-12\left(\delta_{\mathrm{H}} 1.55\right) ; \mathrm{H}-17\left(\delta_{\mathrm{H}} 1.60\right) / \mathrm{H}-22\left(\delta_{\mathrm{H}}\right.$ $3.31,3.62)$ allowed us to assure the configuration at $\mathrm{C}-20$ as $R .{ }^{19-21)}$ Furthermore, the electron impact mass spectrum (EIMS) of 1 showed the fragment ion at $m / z 313\left[\mathrm{M}-\mathrm{C}_{3} \mathrm{H}_{7} \mathrm{O}\right.$ (side chain) $]^{+}$derived from the loss of side chain by the cleavage of $\mathrm{C}-17 / \mathrm{C}-20$ bond. In addition, the fragment ion at $m / z 222\left[\mathrm{M}-\mathrm{C}_{10} \mathrm{H}_{14} \mathrm{O}\right]^{+}$was corresponded to retro-DielsAlder (RDA) cleavage between $\mathrm{A}$ and $\mathrm{B}$ rings. From the above evidence, compound $\mathbf{1}$ was determined as 22-hydroxy23,24,25,26,27-pentanorcucurbit-5-en-3-one, namely pentanorcucurbitacin A. Complete ${ }^{1} \mathrm{H}$ - and ${ }^{13} \mathrm{C}-\mathrm{NMR}$ chemical shifts were established by ${ }^{1} \mathrm{H}-{ }^{1} \mathrm{H}$ COSY, HMQC, HMBC, and NOESY spectra.

The HR-EI-MS of 2 showed a molecular ion at $\mathrm{m} / \mathrm{z}$ 400.2606, which corresponded to the molecular formula, $\mathrm{C}_{25} \mathrm{H}_{36} \mathrm{O}_{4}$, indicating eight degrees of unsaturation. The IR
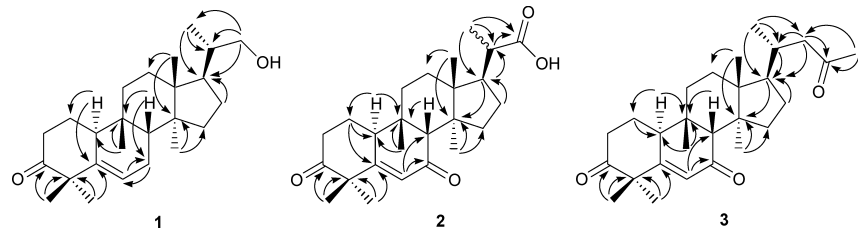

Fig. 2. Main HMBC Correlations of $\mathbf{1}-\mathbf{3}$
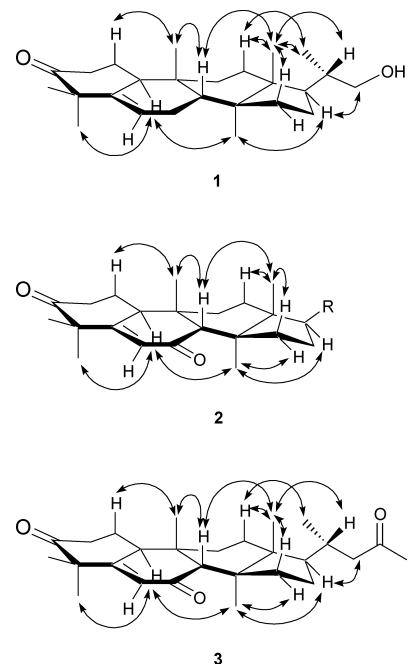

Fig. 3. Main NOESY Correlations of $\mathbf{1}-\mathbf{3}$

spectrum indicated the presence of an isolated ketone, a carboxylic acid, a conjugated ketone, and a conjugated double bond. The presence of an $\alpha, \beta$-unsaturated ketone system was further confirmed by the significant UV absorption at 
$247 \mathrm{~nm}$. The ${ }^{1} \mathrm{H}$ - and ${ }^{13} \mathrm{C}-\mathrm{NMR}$ spectra of 2 (Table 1) displayed signals for five methyl singlets $\left[\delta_{\mathrm{H}} 0.90,0.91,0.94\right.$, $1.31,1.34$ (3H each, s) ], one set of $\alpha, \beta$-unsaturated carbonyl system $\left[\delta_{\mathrm{H}} 6.15(1 \mathrm{H}, \mathrm{d}, J=2.4 \mathrm{~Hz}) ; \delta_{\mathrm{C}} 125.4(\mathrm{~d}), 167.8(\mathrm{~s})\right.$, 202.3 (s)]. The ${ }^{13} \mathrm{C}-\mathrm{NMR}$ spectrum of 2 revealed 25 resonances. The ${ }^{13} \mathrm{C}-\mathrm{NMR}$ data of $\mathbf{2}$ showed close resemblance with those of the known compound, (23E)-25-hydroxycucurbita-5,23-diene-3,7-dione, ${ }^{16)}$ indicated that both compounds exhibited identical structure in rings $\mathrm{A}-\mathrm{D}$ of the tetracyclic skeleton and the ${ }^{13} \mathrm{C}$-NMR signals of C-23-C-27 of the side chain were absent in $\mathbf{2}$. Compound $\mathbf{2}$ was tentatively proposed to exhibit a basic skeleton of 23,24,25,26,27-pentanorcucurbitacin. In turn, the downfield methine signal at $\delta_{\mathrm{H}} 2.50$ $(\mathrm{H}-20)$ as well as the HMBC correlations between $\mathrm{H}-17\left(\delta_{\mathrm{H}}\right.$ $1.97) / \mathrm{C}-20\left(\delta_{\mathrm{C}} 42.2\right) ; \mathrm{H}-20\left(\delta_{\mathrm{H}} 2.50\right) / \mathrm{C}-17\left(\delta_{\mathrm{C}} 46.7\right) ; \mathrm{H}-$ 20/C-22 $\left(\delta_{\mathrm{C}} 180.9\right) ; \mathrm{Me}-21\left(\delta_{\mathrm{H}} 1.21\right) / \mathrm{C}-22$ (Fig. 2$)$ confirmed that the carboxylic acid group was located at C-22 position. The relative configurations of sterogenic $\mathrm{C}$-atoms in the tetracyclic rings were determined by significant NOE correlations between $\mathrm{H}-8\left(\delta_{\mathrm{H}} 2.43\right) / \mathrm{Me}-18\left(\delta_{\mathrm{H}} 0.90\right), \mathrm{Me}-19\left(\delta_{\mathrm{H}}\right.$ $0.94)$ H-10 $\left(\delta_{\mathrm{H}} 2.92\right) / \mathrm{Me}-28\left(\delta_{\mathrm{H}} 1.31\right), \mathrm{Me}-30\left(\delta_{\mathrm{H}} 0.91\right) ; \mathrm{H}-$ $17\left(\delta_{\mathrm{H}} 1.97\right) / \mathrm{Me}-30\left(\delta_{\mathrm{H}} 0.91\right)$ in the NOESY spectrum (Fig. $3)$. The configuration at $\mathrm{C}-20$ was considered as a racemic center due to locating at $\alpha$-position of carbonyl functionality. The EI-MS spectrum of $\mathbf{2}$ showed the fragment ion at $\mathrm{m} / \mathrm{z}$ $327\left[\mathrm{M}-\mathrm{C}_{3} \mathrm{H}_{5} \mathrm{O}_{2} \text { ( side chain) }\right]^{+}$derived from the loss of side chain by the cleavage of $\mathrm{C}-17$ and $\mathrm{C}-20$ bond. In addition, the fragment ion at $m / z 164\left[\mathrm{M}-\mathrm{C}_{15} \mathrm{H}_{24} \mathrm{O}_{2}\right]^{+}$was corresponded to flavone like RDA cleavage. Thus, compound 2 was elucidated as 3,7-dioxo-23,24,25,26,27-pentanorcucurbit-5-en-22-oic acid, namely pentanorcucurbitacin B.

Compound 3 was obtained as a white amorphous powder. The molecular formula was determined as $\mathrm{C}_{27} \mathrm{H}_{40} \mathrm{O}_{3}$ from the HR-EI-MS [M] ${ }^{+} m / z$ 412.2981. In the UV spectrum, a significant absorption maximum at $246 \mathrm{~nm}$ suggested the presence of an $\alpha, \beta$-unsaturated ketone. The IR spectrum displayed absorption bands for a conjugated ketone, a conjugated double, and an isolated cyclohexanone. The ${ }^{1} \mathrm{H}$ - and ${ }^{13} \mathrm{C}-\mathrm{NMR}$ spectra of 3 (Table 1 ) exhibited signals for the presence of five methyl singlets $\left[\delta_{\mathrm{H}} 0.87,0.92,0.93,1.31\right.$, $1.33(3 \mathrm{H}$ each, s) $]$, a secondary methyl $\left[\delta_{\mathrm{H}} 0.89(3 \mathrm{H}, \mathrm{d}\right.$, $J=6.4 \mathrm{~Hz})]$, an acetyl methyl $\left[\delta_{\mathrm{H}} 2.10(\mathrm{~s})\right]$, and one $\alpha, \beta$-unsaturated carbonyl system $\left[\delta_{\mathrm{H}} 6.14(1 \mathrm{H}, \mathrm{d}, J=2.0 \mathrm{~Hz}) ; \delta_{\mathrm{C}}\right.$ 125.4 (d), 168.0 (s), 202.3 (s)]. In turn, the ${ }^{13} \mathrm{C}-\mathrm{NMR}$ spectrum of 3 revealed 27 carbon signals. By comparison of the ${ }^{1} \mathrm{H}$ - and ${ }^{13} \mathrm{C}-\mathrm{NMR}$ data with those of the known compound, (23E)-cucurbita-5,24-diene-3,7,23-trione, ${ }^{17)}$ indicated that both compounds exhibited identical structure in rings $\mathrm{A}-\mathrm{D}$ and the C-25-C-27 NMR signals of side chain were absent in 3. Thus, compound 3 was considered as a 25,26,27-trinorcucurbitacin triterpene with a $\mathrm{C}_{5}$ side chain containing an isolated ketone functionality. The NMR signals for an acetyl methyl $\left[\delta_{\mathrm{H}} 2.10(\mathrm{~s}) ; \delta_{\mathrm{C}} 30.8(\mathrm{~s})\right]$ as well as the HMBC correlations between $\mathrm{H}-20\left(\delta_{\mathrm{H}} 2.06\right) / \mathrm{C}-23\left(\delta_{\mathrm{C}} 209.4\right)$; Me-21 $\left(\delta_{\mathrm{H}}\right.$ $0.89) / \mathrm{C}-22(51.1) ; \mathrm{H}-24\left(\delta_{\mathrm{H}} 2.10\right) / \mathrm{C}-23$ confirmed that the isolated ketone was located at C-23 (Fig. 2). The EI-MS spectrum of $\mathbf{3}$ showed the fragment ion at $\mathrm{m} / \mathrm{z} 369$ $\left[\mathrm{M}-\mathrm{COCH}_{3}\right]^{+}$derived from the loss of an acetyl group. The relative configurations of sterogenic $\mathrm{C}$-atoms in the tetracyclic rings were determined by significant NOE correlations between H-8/Me-18 $\left(\delta_{\mathrm{H}} 0.92\right)$, Me-19 $\left(\delta_{\mathrm{H}} 0.93\right)$; H-10/Me-

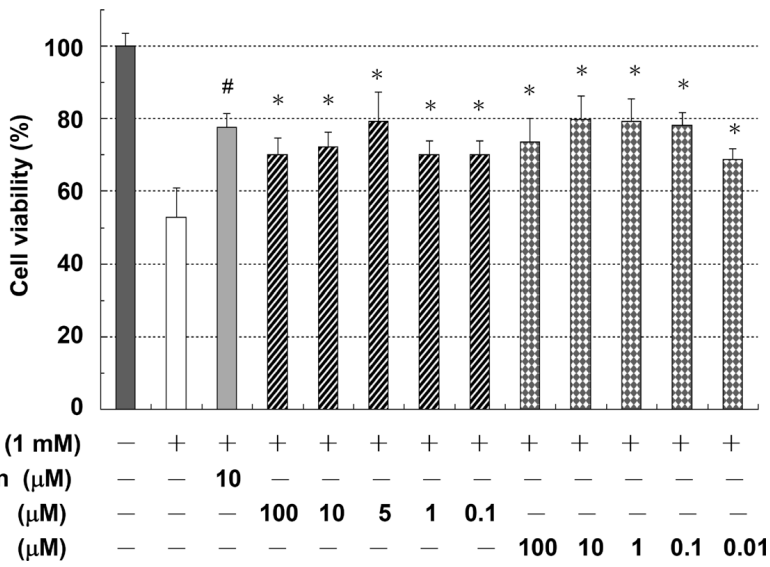

Fig. 4. Cytoprotective Effect of $\mathbf{2}$ and $\mathbf{3}$ on $t$-BHP-Toxicified HepG2 Cells

\# Statistically significant compared with normal data $(p<0.05)$. Statistically significant compared with $t$-BHP control data $(p<0.05)$.

$28\left(\delta_{\mathrm{H}} 1.33\right), \mathrm{Me}-30\left(\delta_{\mathrm{H}} 0.87\right) ; \mathrm{H}-17\left(\delta_{\mathrm{H}} 1.50\right) / \mathrm{Me}-30$ in the NOESY spectrum (Fig. 3 ). The configuration at C-20 was determined as $R$ on the basis of the NOESY correlations between H-20 $\left(\delta_{\mathrm{H}} 2.06\right) / \mathrm{Me}-18 ; \mathrm{Me}-21\left(\delta_{\mathrm{H}} 0.89\right) / \mathrm{H}-12\left(\delta_{\mathrm{H}}\right.$ $1.62) ; \mathrm{H}-22\left(\delta_{\mathrm{H}} 2.16\right) / \mathrm{H}-17\left(\delta_{\mathrm{H}} 1.50\right) .{ }^{19-21)}$ From the above evidence, compound 3 was characterized as 25,26,27-trinorcucurbit-5-ene-3,7,23-trione. Complete ${ }^{1} \mathrm{H}$ - and ${ }^{13} \mathrm{C}-\mathrm{NMR}$ chemical shifts were established by ${ }^{1} \mathrm{H}-{ }^{1} \mathrm{H}$ COSY, HMQC, HMBC, and NOESY spectra.

Compounds $\mathbf{2}$ and $\mathbf{3}$ were tested for their cytotoxic activity toward human hepatoma HepG2 cells with fluorouracil (5FU) as a positive control $\left(\mathrm{IC}_{50}=1.9 \mu \mathrm{M}\right)$ by using the MTT [3-(4,5-dimethylthiazol-2-yl)-2,5-diphenyltetrazolium bromide] colorimetric method based on the described procedures. ${ }^{18)}$ The two compounds were not cytotoxic against the HepG2 cell line up to $100 \mu \mathrm{M}$. The cytoprotective effects of compounds $\mathbf{2}$ and $\mathbf{3}$ on HepG2 cells injured by tert-butyl hydroperoxide ( $t$-BHP) were performed in an assay described earlier. ${ }^{22)}$ The pretreatment of compounds $\mathbf{2}$ and $\mathbf{3}$ on HepG2 cells inhibited $t$-BHP-induced cytotoxicity. Compound $\mathbf{2}$ at a dose of $5 \mu \mathrm{M}$ protected the $t$-BHP-induced cytotoxicity of HepG 2 to $55.2 \%$ of control group. Compound $\mathbf{3}$ at a dose of $10 \mu \mathrm{M}$ protected the $t$-BHP-induced cytotoxicity of HepG2 to $56.9 \%$ of control group. The protective effects of compounds $\mathbf{2}$ and $\mathbf{3}$ were similar to that of silybin, a commercial agent, which protected the $t$-BHP-induced cytotoxicity of HepG2 to $52.5 \%$ of control group at a dose of $10 \mu \mathrm{M}$ (Fig. 4).

\section{Experimental}

General Experimental Procedures Optical rotations were measured on a JASCO DIP-180 digital spectropolarimeter. UV spectra were measured in $\mathrm{MeOH}$ using a Shimadzu UV-1601PC spectrophotometer. IR spectra were obtained on a Nicolet 510P FT-IR spectrometer. NMR spectra were recorded in $\mathrm{CDCl}_{3}$ at room temperature on a Varian Mercury plus 400 NMR spectrometer, and the solvent resonance was used as internal shift reference [tetramethyl silane (TMS) as standard]. The 2D NMR spectra were recorded by using standard pulse sequences. EI-MS and HR-EI-MS were recorded on Finnigan TSQ-700 and JEOL SX-102A mass spectrometers, respectively. TLC was carried out on silica gel $60 \mathrm{~F}_{254}$ plates (Merck, Germany). Column chromatography was performed on silica gel (230 - 400 mesh ASTM, Merck). HPLC was performed on a Hitachi L-7000 chromatograph with a Lichrosorb Si gel $60(5 \mu \mathrm{m})$ column $(250 \times 10 \mathrm{~mm})$.

Plant Material The stems of Momordica charantia were collected in Pingtung County, Taiwan in July, 2003. Identification of the voucher specimens was done by Prof. Sheng-Zehn Yang, Curator of Herbarium, National 
Pingtung University of Science and Technology. A voucher specimen (no. 2013) was deposited at the Herbarium of National Pingtung University of Science and Technology.

Extraction and Isolation The air-dried stems $(18 \mathrm{~kg})$ of $M$. charantia were extracted with $\mathrm{MeOH}(3 \times 301)$ at room temperature $(7 \mathrm{~d}$ each $)$. The combined $\mathrm{MeOH}$ extract was evaporated under reduced pressure to afford a black residue, which was suspended in $\mathrm{H}_{2} \mathrm{O}(31)$, and then partitioned sequentially, using EtOAc and $n-\mathrm{BuOH}(3 \times 21)$ as solvent. The EtOAc fraction $(386 \mathrm{~g})$ was chromatographed on a silica gel column $(120 \times 10 \mathrm{~cm})$, using solvent mixtures of $n$-hexane and EtOAc with increasing polarity as eluents. Eleven fractions were collected as follows: 1 [5000 ml, $n$-hexane], 2 [4000 ml, $n$-hexane-EtOAc (49:1)], 3 [4000 ml, $n$-hexane-EtOAc (19:1)], $4[4000 \mathrm{ml}, n$-hexane-EtOAc $(9: 1)], 5$ [4000 ml, $n$-hexane-EtOAc $(17: 3)]$, 6 [4000 ml, $n$-hexane-EtOAc $(8: 2)], 7[4000 \mathrm{ml}, n$-hexane-EtOAc $(7: 3)], 8$ [3000 ml, $n$-hexane-EtOAc $(5: 5)], 9$ [3000 ml, $n$-hexane-EtOAc ( $4: 6)], 10$ [3000 $\mathrm{ml}, n$-hexane-EtOAc $(2: 8)]$, and $11(6000 \mathrm{ml}$, EtOAc). Fraction 6 was further chromatographed on a silica gel column $(5 \times 45 \mathrm{~cm})$, eluted with $\mathrm{CH}_{2} \mathrm{Cl}_{2}$-EtOAc $(8: 1$ to $0: 1)$ to give seven fractions (each about $700 \mathrm{ml}$ ), $6 \mathrm{~A}-6 \mathrm{G}$. Fr. $6 \mathrm{E}$ was subjected to column chromatographed over silica gel eluted with $n$-hexane- $\mathrm{CH}_{2} \mathrm{Cl}_{2}$-EtOAc $(5: 3: 1)$ and semipreparative HPLC eluted with $n$-hexane-EtOAc $(7: 3)$ to yield $1(1.1 \mathrm{mg})$. Fraction 7 was further chromatographed on a silica gel column $(5 \times 45 \mathrm{~cm})$, eluted with $\mathrm{CH}_{2} \mathrm{Cl}_{2}-$ EtOAc $(8: 1$ to $0: 1)$ to resolve into seven fractions (each about $600 \mathrm{ml}$ ), 7A-7G. Fr. 7C was subjected to column chromatography over silica gel eluted with $\mathrm{CH}_{2} \mathrm{Cl}_{2}$-EtOAc $(15: 1)$ and semipreparative HPLC eluted with $n$-hexane-EtOAc $(7: 3)$ to yield $3(6 \mathrm{mg})$. Fraction 8 was further purified through a silica gel column $(5 \times 45 \mathrm{~cm})$, eluted with $\mathrm{CH}_{2} \mathrm{Cl}_{2}-\mathrm{EtOAc}$ $(7: 1)$ to obtain six fractions (each about $500 \mathrm{ml}$ ), $8 \mathrm{~A}-8 \mathrm{~F}$. Fr. $8 \mathrm{~F}$ was subjected to column chromatographed over $\mathrm{Si}$ gel eluted with $n$ hexane- $\mathrm{CH}_{2} \mathrm{Cl}_{2}-$ EtOAc $(3: 3: 1)$ and semipreparative HPLC eluted with $\mathrm{CH}_{2} \mathrm{Cl}_{2}-$ EtOAc $(3: 2)$ to yield $2(4.5 \mathrm{mg})$

22-Hydroxy-23,24,25,26,27-pentanorcucurbit-5-en-3-one (1): Amorphous white powder; $[\alpha]_{\mathrm{D}}^{25}+36.7(c=0.10, \mathrm{MeOH}) ;{ }^{1} \mathrm{H}$ - and ${ }^{13} \mathrm{C}$-NMR data, see Table 1; IR (KBr) $v_{\max } 3422,3075,2950,2872,1708,1654,1465,1382$, 1270, 1031, 977, 734, $705 \mathrm{~cm}^{-1}$; EI-MS m/z: $372\left[\mathrm{M}^{+}\right.$(1), 357 (2), 354 (1), 313 (1), 271 (3), 222 (88), 207 (52), 189 (19), 163 (100), 133 (30), 123 (58), 105 (62), 91 (60); HR-EI-MS m/z: 372.3048 (Calcd for $\mathrm{C}_{25} \mathrm{H}_{40} \mathrm{O}_{2} 372.3030$ ).

3,7-Dioxo-23,24,25,26,27-pentanorcucurbit-5-en-22-oic Acid (2): Amorphous white powder; $[\alpha]_{\mathrm{D}}^{25}+38.7(c=0.36, \mathrm{MeOH}) ;{ }^{1} \mathrm{H}$ - and ${ }^{13} \mathrm{C}-\mathrm{NMR}$ data, see Table 1; IR (KBr) $v_{\max } 3427,3072,2950,2872,1693,1645,1460,1377$, $1260,1216,1124,1036,886,842 \mathrm{~cm}^{-1}$; UV (MeOH) $\lambda_{\max }(\log \varepsilon) 247(3.53)$ nm; EI-MS m/z: $400\left(\mathrm{M}^{+}, 100\right), 385$ (68), 372 (19), 357 (15), 339 (20), 327 (14), 311 (21), 263 (30), 205 (34), 164 (45), 136 (38), 121 (20); HR-EI-MS $m / z$ : 400.2606 (Calcd for $\mathrm{C}_{25} \mathrm{H}_{36} \mathrm{O}_{4} 400.2614$ ).

25,26,27-Trinorcucurbit-5-ene-3,7,23-trione (3): Amorphous white powder; $[\alpha]_{\mathrm{D}}^{25}+86.2(c=0.37, \mathrm{MeOH}) ;{ }^{1} \mathrm{H}$ - and ${ }^{13} \mathrm{C}-\mathrm{NMR}$ data, see Table 1; IR $(\mathrm{KBr}) \mathrm{cm}^{-1}: 3041,2955,2882,1718,1645,1616,1465,1382,1353,1294$, 1250, 1158, 886; UV (MeOH) $\lambda_{\max }(\log \varepsilon) 203(4.21), 246$ (3.55) nm; EIMS $m / z: 412\left[\mathrm{M}^{+}(4), 369\right.$ (7), 355 (16), 339 (8), 205 (24), 149 (25), 136 (42), 121 (100), 107 (69), 93 (89), 79 (76), 67 (73); HR-EI-MS m/z: 412.2981 (Calcd for $\mathrm{C}_{27} \mathrm{H}_{40} \mathrm{O}_{3} 412.2978$ ).

Cytoprotective Assay HepG2 cells (hepatocellular carcinoma cell line) were cultured in Dulbecco's modified Eagle's medium (DMEM) supplemented with $10 \%$ fetal bovine serum, L-glutamine $2 \mathrm{~mm}, 1 \%$ penicillin/streptomycin (penicillin $10000 \mathrm{U} / \mathrm{ml}$ and streptomycin $10 \mathrm{mg} / \mathrm{ml}$ ) in a humidified atmosphere of $5 \% \mathrm{CO}_{2}$ at $37^{\circ} \mathrm{C}$. The protective effect of compounds $\mathbf{2}$ and $\mathbf{3}$ on HepG2 cells injured by $t$-BHP was measured using the MTT colorimetric assay based on the described procedures with some modifications. ${ }^{22}$ Briefly, HepG2 cells were plated on a 96-well plate with $1 \times 10^{4}$ cells per well. The cells were treated with different concentrations of test compounds. After preincubated for $2 \mathrm{~h}$, the cultured media were changed to the media containing $t$-BHP $(100 \mathrm{~mm})$, incubated for $3 \mathrm{~h}$ and then rinsed with phosphatebuffered saline. Subsequently, the wells were incubated with the MTT ( $100 \mu \mathrm{l} /$ well concentrated at $5 \mathrm{mg} / \mathrm{ml}$ ) at $37^{\circ} \mathrm{C}$ for $4 \mathrm{~h}$. After removing the supernatant, $200 \mu \mathrm{l}$ of dimethyl sulfoxide (DMSO) was added to redissolve the formazan crystals. Absorbance at $550 \mathrm{~nm}$ was measured to estimate sur- vived cells.

Statistic Analysis The significance of various treatments was determined by the Student's $t$-test. The results were expressed as mean \pm S.E.M. Differents were considered significant if $p<0.05$.

Acknowledgements This research was supported by Grants to Chi-I Chang from the National Science Council of Taiwan (NSC 97-2317-B-020002 and NSC 98-2622-B-020-002-CC1). This study was supported in part by Taiwan Department of Health Clinical Trial and Research Center of Excellence (DOH99-TD-B-111-004) and Cancer Research Center of Excellence (DOH99-TD-C-111-005). We thank Ms. Shu-Yun Sun and Ms. LihMei Sheu for the EI-MS and HR-EI-MS measurement in the Instrumentation Center of the College of Science, National Taiwan University and National Chung Hsing University. We are also grateful to the National Center for High-Performance Computing for computer time and facilities.

\section{References}

1) Rathi S. S., Grover J. K., Vats V., Phytother. Res., 16, 236-243 (2002).

2) Kobori M., Nakayama H., Fukushima K., Ohnishi-Kameyama M., Ono H., Fukushima T., Akimoto Y., Masumoto S., Yukizaki C., Hoshi Y., Deguchi T., Yoshida M., J. Agric. Food Chem., 56, 4004-4011 (2008).

3) Harinantenaina L., Tanaka M., Takaoka S., Oda M., Mogami O., Uchida M., Asakawa Y., Chem. Pharm. Bull., 54, 1017-1021 (2006).

4) Fatope M. O., Takeda Y., Yamashita H., Okabe H., Yamauchi T., J. Nat. Prod., 53, 1491-1497 (1990).

5) Kimura Y., Akihisa T., Yuasa N., Ukiya M., Suzuki T., Toriyama M., Motohashi S., Tokuda H., J. Nat. Prod., 68, 807-809 (2005).

6) Nakamura S., Murakami T., Nakamura J., Kobayashi H., Matsuda H., Yoshikawa M., Chem. Pharm. Bull., 54, 1545-1550 (2006).

7) Li Q. Y., Chen H. B., Liu Z. M., Wang B., Zhao Y. Y., Magn. Reson. Chem., 45, 451-456 (2007).

8) Akihisa T., Higo N., Tokuda H., Ukiya M., Akazawa H., Tochigi Y., Kimura Y., Suzuki T., Nishino H., J. Nat. Prod., 70, 1233-1239 (2007).

9) Matsuda H., Nakamura S., Murakami T., Yoshikawa M., Heterocycles, 71, 331-341 (2007).

10) Liu Y., Ali Z., Khan I. A., Planta Med., 74, 1291-1294 (2008).

11) Miyahara Y., Okabe H., Yamauchi T., Chem. Pharm. Bull., 29, $1561-$ 1566 (1981).

12) Okabe H., Miyahara Y., Yamauchi T., Miyahara K., Kawasaki T., Chem. Pharm. Bull., 28, 2753-2762 (1980).

13) Chen J. C., Tian R. R., Qiu M. H., Lu L., Zheng Y. T., Zhang Z. Q., Phytochemistry, 69, 1043-1048 (2008).

14) Yasuda M., Iwamoto M., Okabe H., Yamauchi T., Chem. Pharm. Bull., 32, 2044-2047 (1984).

15) Chen J. C., Liu W. Q., Lu L., Qiu M. H., Zheng Y. T., Yang L. M., Zhang X. M., Zhou L., Li Z. R., Phytochemistry, 70, 133-140 (2009).

16) Chang C. I., Chen C. R., Liao Y. W., Cheng H. L., Chen Y. C., Chou C. H., J. Nat. Prod., 69, 1168-1171 (2006).

17) Chang C. I., Chen C. R., Liao Y. W., Cheng H. L., Chen Y. C., Chou C. H., J. Nat. Prod., 71, 1327-1330 (2008).

18) Chang C. I., Chen C. R., Liao Y. W., Shih W. L., Cheng H. L., Tzeng C. Y., Li J. W., Kung M. T., Chem. Pharm. Bull., 58, 225-229 (2010).

19) Antonov A. S., Afiyatullov S. S., Kalinovsky A. I., Ponomarenko L. P., Dmitrenok P. S., Aminin D. L., Agafonova I. G., Stonik V. A., J. Nat. Prod., 66, 1082-1088 (2003).

20) Antonov A. S., Kalinovsky A. I., Stonik V. A., Afiyatullov S. S., Aminin D. L., Dmitrenok P. S., Mollo E., Cimino G., J. Nat. Prod., 70, $169-178$ (2007).

21) Mansoor T. A., Hong J., Lee C. O., Bae S. J., Im K. S., Jung J. H., J. Nat. Prod., 68, 331-336 (2005).

22) Lee H. U., Bae E. A., Han M. J., Kim D. H., Biol. Pharm. Bull., 28, $1992-1994$ (2005). 